\title{
Hubungan Kebiasaan Membaca Alqur'an dan Aktivitas Fisik dengan Demensia pada Lanjut Usia
}

\section{The Relationship Between Recite Alqur'an Habits and Physical Activity with Dementia in the Elderly}

\author{
Surahmawati $^{1 *}$, Yuni Kartika ${ }^{2}$, Sitti Raodhah ${ }^{3}$ \\ 1. Universitas Islam Negeri Alauddin Makassar, Indonesia \\ 2. Universitas Islam Negeri Alauddin Makassar, Indonesia \\ 3. Universitas Islam Negeri Alauddin Makassar, Indonesia \\ *Email Korespondensi : surahma.wati45@gmail.com
}

\begin{abstract}
Abstrak
Latar belakang: Demensia merupakan penyakit yang paling sering ditemukan pada orang lanjut usia (lansia). WHO mencatat ada sekitar 50 juta orang penduduk dunia yang didiagnosis dengan demensia dan sekitar 10 juta kasus baru setiap tahun.

Tujuan : Untuk mengetahui korelasi/hubungan kebiasaan membaca Al-Qur'an dan aktivitas fisik pada demensia lanjut usia yang berkunjung di posyandu lansia desa Baringeng kabupaten Soppeng, Provinsi Sulawesi Selatan tahun 2020

Metode: Jenis Penelitian ini adalah observasional analitik menggunakan desain cross-sectional, dengan jumlah responden sebanyak 53 orang usia lanjut, jumlah sampelnya diambil secara total sampling. Instrumen yang digunakan adalah kuesioner dan data yang diperoleh diuji dengan uji korelasi spearman rank.

Hasil : Variebel kebiasaan membaca Al-Qur'an dan aktivitas fisik keduanya memiliki hubungan dengan kejadian demensia dengan masing-masing $p$-value $=0.000$

Kesimpulan: Kebiasaan membaca Al-Qur'an serta aktivitas fisik berkorelasi dengan kejadian demensia pada lanjut usia yang berkunjung di posyandu lansia desa Baringeng tahun 2020.
\end{abstract}

Kata kunci: aktivitas fisik; demensia; kebiasaan membaca Al-Qur'an

\begin{abstract}
Background: Dementia is a disease most often found in the elderly (elderly). WHO noted that there are about 50 million people in the world who are diagnosed with dementia and about 10 million new cases every year.

Objective: To determine the correlation/relationship between the habit of reciting the Qur'an and physical activity in elderly dementia visiting the elderly posyandu in Baringeng village, Soppeng district, South Sulawesi Province in 2020.

Methods: This type of research is analytic observational using a cross-sectional design, with the number of respondents as many as 53 elderly people, the number of samples taken by total sampling. The instrument used was a questionnaire and the data obtained were tested with the Spearman rank correlation test.

Results: The variable reciting habits of the Qur'an and physical activity both have a relationship with the incidence of dementia with each p-value $=0.000$

Conclusion: The habit of reciting the Qur'an and physical activity are correlated with the incidence of dementia in the elderly visiting the elderly posyandu in Baringeng village in 2020.
\end{abstract}

Keywords: dementia; physical activity; the habit of reciting Al-Qur'an 


\section{PENDAHULUAN}

Menurut data WHO kejadian demensia mengalami peningkatan yang sangat cepat yakni 46,8 atau 50 juta orang di seluruh dunia. Setiap 3 detik, terdapat 1 orang yang mengalami demensia, dan selalu ada kasus baru setiap tahunnya yaitu sekitar 10 juta (1).

Pada tahun 2016 jumlah penyakit demensia di Indonesia 1,2 juta orang. Jika dilihat dari perkembangan kasusnya, maka diprediksikan jumlah kejadian demensia akan menjadi 2 juta orang pada tahun 2030 dan meningkat lagi menjadi 4 juta orang di tahun 2050 mendatang (2).

Demensia merupakan salah satu penyebab meningkatnya disabilitas fungsional pada lanjut usia. Data Riskesdas 2018 menunjukkan bahwa disabilitas pada lanjut usia kebanyakan dialami oleh jenis kelamin laki-laki yaitu sebanyak $77,8 \%$ dan $71,1 \%$ terjadi pada perempuan. Secara nasional, terdapat sekitar 22\% lansia dengan ketergantungan ringan, 74,3 yang mandiri dan sebagian kecil lainnya mengalami ketergantungan sedang, berat hingga total (3).

Hasil survey Badan Pusat Statistik tahun 2018 jumlah usia lanjut di Sulawesi Selatan sebanyak 1.489.011 jiwa.(4). Dari data profil penduduk Sulawesi Selatan hasil supas 2015 persentase penduduk lanjut usia tertinggi berada di kabupaten Soppeng yaitu sebanyak 14,98\%. Jumlah lanjut usia (lansia) yang berada di kabupaten Soppeng sebesar 32.247 jiwa. Desa Baringeng adalah desa yang berada di wilayah Puskesmas Baringeng kabupaten Soppeng dengan jumlah lansia tertinggi dibanding desa lainnya yang berada di wilayah puskesmas tersebut, yaitu sekitar 698 lansia.(5). Dari data awal peneliti memperoleh bahwa ada sekitar 53 orang lanjut usia yang selalu berkunjung ke posyandu Lansia desa Baringeng. Puskesmas Baringeng itu sendiri termasuk dalam 5 besar jumlah lansia tertinggi di Kabupaten Soppeng.

Seiring dengan peningkatan jumlah lansia, maka akan terjadi pula peningkatan pada penyakit yang berhubungan dengan penuaan. Beberapa organ tubuh seperti otak yang berfungsi mengatur sistem tubuh dan pusat kognitif akan sangat rentan untuk mengalami proses degeneratif. Salah satu penyakit degeneratif otak yang biasa kita kenal adalah demensia. Saat proses degenerasi mengenai otak, maka fungsi otak akan menurun dan ini menyebabkan gangguan pada fungsi kerja sehari-hari, sehingga lanjut usia akan menjadi ketergantungan dan menjadi beban keluarga (6).

Tingkat kepedulian dan pengetahuan masyarakat tentang demensia masih sangat kurang. Demensia masih dianggap sebagai hal yang biasa yang merupakan akibat dari menuanya seseorang. Kebanyakan masyarakat mencari pengobatan jika gangguan kognitif dan gangguan prilaku yang dialami lansia sudah tergolong berat sehingga tentu saja penanganannya tidak akan memberikan hasil yang maksimal. Setiap manusia tentu mengalami penuaan dan proses ini tidak dapat dihentikan namun kita dapat mengupayakan perlambatannya (7).

Telah banyak hasil penelitian sebelumnya yang membuktikan bahwa proses penuaan otak dapat diperlambat dengan cara melakukan berbagai latihan. Penelitian Adreany (2017) di desa Ngesrep kecamatan Ngemplak Kabupaten Boyolali Jawa Tengah, yang mana dalam penelitiannya ia memberi perlakuan berupa latihan fisik pada lansia berupa senam irama, latihan kekuatan yang dilakukan 2 kali dalam seminggu, durasi 30-45 menit selama 6 minggu dan didapatkan hasil perubahan nilai kognitif pada kelompok perlakuan setelah diberikan latihan fisik, poin meningkat menjadi 2,10 dari nilai Mini Mental State Examination (MMSE) sebelum diberikan perlakuan (8). Ada juga penelitian yang dilakukan oleh Nety Mawarda (2019) di Posyandu Lansia Wulan Erma kelurahan Mananggal Surabaya yang mendapatkan hasil bahwa terdapat pengaruh terapi puzzle dan gerak senam pada kejadian demensia $(\mathrm{p}=$ 0,015) (9). Penelitian serupa juga dilakukan oleh Aisyatu (2020) yang mana didapatkan hasil bahwa terjadi peningkatan pada fungsi kognitif lansia yang demensia setelah diberikan latihan senam otak selama 1 minggu, durasi 1x 15 menit, didapatkan skor MMSE meningkat dengan rentang 0-16, namun hasil yang didapatkan tidak terlalu signifikan disebabkan durasi 
intervensi yang singkat sehingga dari hasil penelitiannya ia menyarankan pada lansia untuk menambah durasi waktu senam otak menjadi 2-3 kali dengan waktu 15-20 menit untuk memberikan hasil yang lebih baik lagi (10).

Selain aktivitas fisik demensia juga dapat diperlambat melalui aktivitas spiritual seperti mengaji atau membaca Al-Qur'an. Hasil penelitian Irawati (2019) pada lansia di Posyandu Lansia Bantul Yogyakarta yang mana mendapatkan hasil bahwa kebiasaan mengaji/membaca Al-Qur'an pada lansia berhubungan dengan fungsi kognitifnya ( $\mathrm{p}<0.05)$. Sebagian besar lansia yang selalu mengaji atau membaca Al-Qur'an tidak mengalami gangguan pada fungsi kognitifnya sehingga mengalami perlambatan dalam proses penurunan kognitifnya (11). Ada juga penelitian Linda Rosdiana (2017) pada lansia di PSTW Budi Mulia 02 Cengkareng Jakarta Barat, dimana hasilnya menunjukkan adanya keterkaitan antara kebiasaan mengaji dengan demensia ( $\mathrm{p}=0,028$, $\mathrm{p}$-value $<\alpha=0,05$ ). Kebiasaan baca Al-Qur'an/mengaji yang dilakukan dengan rutin ataupun tidak rutin dapat memperbaiki fungsi kognitif, karena dapat menjaga dan mempertahankan daya ingat seseorang (12). Penelitian serupa juga dilakukan oleh Rahmawati (2020) yang mendapatkan hasil bahwa frekuensi membaca Al-Qur'an dan berdzikir ada hubungannya dengan kejadian demensia dengan nilai $\mathrm{p}=0,000$, sebanyak $60 \%$ lansia yang tidak baca Al-Qur'an dan juga tidak berdzikir mengalami demensia berat, sedangkan yang rutin membaca Al-Qur'an dan berdzikir hanya sekitar 8,9\% mengalami demensia berat (13).

Dengan melihat fenomena banyaknya jumlah lansia di kabupaten Soppeng khususnya di desa Baringeng, maka kemungkinan besar risiko kejadian demensia juga dapat terjadi di tempat ini, namun berdasarkan hasil pengamatan awal peneliti melihat bahwa rata-rata lansia yang ada di desa tersebut fisiknya terlihat masih kuat dalam beraktivitas, baik itu ke tempat ibadah, ke kebun dan lain-lain. Pada umumnya lansia di daerah tersebut kebanyakan masih aktif mengikuti pengajian di mesjid, dan sebagian besar lansia juga ada yang mengisi aktivitas kesehariannya dengan mengajarkan anak-anak membaca Al-Qur'an. Dari data kunjungan posyandu lansia bulan desember 2019, ada sekitar 53 lansia yang datang ke posyandu lansia di desa Baringeng kabupaten Soppeng, namun peneliti tidak mendapatkan satupun catatan atau data baik itu di posyandu lansia ataupun di puskesmas tentang jumlah penderita demensia di desa tersebut, padahal jika diasumsikan lansia yang berkunjung ke Posyandu itu adalah lansia yang memiliki riwayat penyakit yang berpotensi berpengaruh pada kemampuan aktivitas fisik atau kognitifnya. Peneliti beranggapan bahwa tidak tersedianya data kasus demensia di Puskesmas Baringeng bisa saja disebabkan karena petugas kesehatan kurang mampu mendeteksi dini kejadian demensia, atau bisa juga disebabkan karena memang tidak ditemukan penyakit demensia di tempat ini karena adanya kebiasaan-kebiasaan positif yang sering dilakukan oleh lansia seperti aktivitas fisik dan membaca Al-Qur'an, yang mana diketahui banyak penelitian terdahulu yang menyimpulkan bahwa aktivitas positif dapat memperlambat demensia. Dari fenomena ini penulis memandang perlu untuk melakukan penelitian tentang demensia di tempat tersebut, meskipun telah banyak penelitian-penelitian terdahulu terkait demensia, namun kebanyakan hanya meneliti dari satu sisi saja misalnya hanya menghubungkan aktivitas fisik dengan fungsi kognitif atau hanya menghubungkan kebiasaan membaca Al-Qur'an (mengaji) dengan fungsi kognitif, masih jarang yang meneliti kedua variabel tersebut sekaligus, dan belum pernah ada penelitian terkait demensia di Kabupaten Soppeng. Dari hal yang telah dikemukakan di atas, maka peneliti memandang perlu untuk meneliti dengan mengambil dua komponen yakni aktivitas fisik dan kebiasaan membaca Al-Qur'an yang dihubungkan terhadap kejadian demensia. 


\section{METODE}

Penelitian yang dilakukan ini adalah observasional analitik yang memakai desain crosssectional dan pelaksanaannya pada bulan September-Oktober 2020. Populasi adalah lanjut usia/lansia yang berada di wilayah kerja posyandu lansia desa Baringeng Kabupaten Soppeng Provinsi Sulawesi Selatan. Jumlah responden adalah 53 orang lanjut usia diambil dengan cara total sampling, data dikumpulkan melalui kuesioner dan dianalisis secara univariat dan bivariat. Kuesioner yang dipakai terdiri dari tiga bagian; kuesioner pertama terkait identitas responden serta pertanyaan tentang kebiasaan membaca Al-Qur'an. Kuesioner kedua menggunakan kuesioner baku Physical Activities Scale for the Elderly (PASE) oleh New England Research Institude (1991) untuk mengukur aktivitas fisik yang dilakukan oleh lansia dan kuesioner ketiga menggunakan kuesioner baku MMSE oleh Folstein (1975) untuk mengukur tingkat demensia pada lansia. Tidak dilakukan uji validitas pada instrumen PASE dan MMSE karena sudah merupakan kuesioner baku. Uji validitas hanya dilakukan pada instrument yang terkait dengan kebiasaan membaca Al-Qur'an untuk menilai karakteristik, intensitas dan durasi responden dalam membaca Al-Qur'an. Uji validitas dilakukan terhadap 30 responden sehingga pengambilan keputusan dinilai valid dimana nilai $\mathrm{r}$ hitung $>\mathrm{r}$ tabel $=$ 0.361 dengan taraf signifikansi 5\%. Uji validitas telah dilakukan pada semua soal/pertanyaan yang terdapat dalam kuesioner. Pertanyaan-pertanyaan di dalam kuesioner kebiasaan membaca Al- Qur'an semuanya telah dinyatakan valid dengan nilai r 0,529-0,900.

Analisis univariat digunakan untuk melihat distribusi frekuensi dari variabel independen dan variabel dependen, sedangkan analisis bivariat untuk melihat keterkaitan atau hubungan antara keduanya yakni variabel independen dan variabel dependen dengan menggunakan uji statistik Correlation spearman rank.

Penelitian ini telah mendapat ijin etik dari Komite Etik UIN Alauddin Makassar dengan nomor : B.017/KEPK/FKIK/IX/2020. Seluruh responden telah menyatakan kesediaannya untuk berpartisipasi sebagai responden dalam penelitian ini.

\section{HASIL}

Tabel 1. Distribusi Frekuensi Berdasarkan Karakteristik Responden

\begin{tabular}{lcc}
\hline \multirow{2}{*}{ Karakteristik Responden } & \multicolumn{2}{c}{ Total } \\
\cline { 2 - 3 } Umur & N & Persen \\
$60-74$ & 36 & \\
$74-90$ & 17 & 67,9 \\
\hline Jumlah & 53 & 32,1 \\
\hline Jenis Kelamin & & 100 \\
Laki-laki & 14 & \\
Perempuan & 39 & 26,4 \\
\hline Jumlah & 53 & 73,6 \\
\hline Pendidikan Terakhir & & 100 \\
Tidak tamat SD & 21 & 39,6 \\
SD & 12 & 22,6 \\
SMP & 10 & 19 \\
SMA & 4 & 7,5 \\
Perguruan Tinggi & 6 & 11,3 \\
\hline Jumlah & 53 & 100 \\
\hline
\end{tabular}

Sumber : Data Primer, 2020 
Berdasarkan tabel 1 menunjukkan bahwa dari 53 orang, kebanyakan adalah lansia yang berumur 60-74 tahun yaitu 36 orang (67.9\%), sedangkan dari jenis kelamin yang terbanyak adalah perempuan yaitu $39(73.6 \%)$ orang, dan dilihat dari latar belakang pendidikan mayoritas responden tidak tamat SD yaitu $21(39,6 \%)$ orang.

Tabel 2. Hubungan antara Kebiasaan Membaca Al-Qur'an dengan Demensia di Posyandu Lansia Desa Baringeng Tahun 2020

\begin{tabular}{|c|c|c|c|c|c|c|c|c|c|}
\hline \multirow{3}{*}{$\begin{array}{l}\text { Kebiasaan Membaca } \\
\text { Al-Qur'an }\end{array}$} & \multicolumn{6}{|c|}{ Demensia } & \multirow{2}{*}{\multicolumn{2}{|c|}{ Total }} & \multirow{2}{*}{$\begin{array}{c}P \\
\text { value }\end{array}$} \\
\hline & \multicolumn{2}{|c|}{ Berat } & \multicolumn{2}{|c|}{ Ringan } & \multicolumn{2}{|c|}{$\begin{array}{c}\text { Tidak } \\
\text { Demensia }\end{array}$} & & & \\
\hline & n & $\%$ & $\mathbf{n}$ & $\%$ & $\mathrm{n}$ & $\%$ & $\mathbf{N}$ & $\%$ & \multirow{4}{*}{0.000} \\
\hline Cukup & 0 & 0.0 & 2 & 6.1 & 31 & 93.9 & 33 & 100 & \\
\hline Kurang & 3 & 15.0 & 14 & 70.0 & 3 & 15.0 & 20 & 100 & \\
\hline Total & 3 & 5.7 & 16 & 30.2 & 34 & 64.1 & 53 & 100 & \\
\hline
\end{tabular}

Sumber : Data Primer, 2020

Berdasarkan Tabel 2 menunjukkan bahwa frekuensi tertinggi adalah yang memiliki kebiasaan membaca Al-Qur'an cukup yaitu 31 (93,9\%) lansia tidak mengalami demensia, dan frekuensi terendah adalah yang memiliki kebiasaan membaca Al-Qur'an kurang, mengalami demensia berat yaitu 3 responden (15\%).

Berdasarkan uji korelasi spearman rank didapatkan $p$-value $=0.000$ atau $(\mathrm{p}<\alpha)$ dapat disimpulkan bahwa $\mathrm{H}_{0}$ ditolak dan $\mathrm{H}_{1}$ diterima yang artinya bahwa terdapat hubungan antara kebiasaan membaca Al-Qur'an dengan demensia pada lansia.

Tabel 3. Hubungan antara Aktivitas Fisik dengan Demensia di Posyandu Lansia Desa Baringeng Tahun 2020

\begin{tabular}{|c|c|c|c|c|c|c|c|c|c|}
\hline \multirow{3}{*}{ Aktivitas Fisik } & \multicolumn{6}{|c|}{ Demensia } & \multirow{2}{*}{\multicolumn{2}{|c|}{ Total }} & \multirow{2}{*}{ Pvalue } \\
\hline & \multicolumn{2}{|c|}{ Berat } & \multicolumn{2}{|c|}{ Ringan } & \multicolumn{2}{|c|}{$\begin{array}{c}\text { Tidak } \\
\text { Demensia }\end{array}$} & & & \\
\hline & n & $\%$ & n & $\%$ & $\mathbf{n}$ & $\%$ & $\mathbf{N}$ & $\%$ & \multirow{4}{*}{0.000} \\
\hline Kurang & 3 & 30.0 & 7 & 70.0 & 0 & 0.0 & 10 & 100 & \\
\hline Cukup & 0 & 0.0 & 9 & 20.9 & 34 & 79.1 & 43 & 100 & \\
\hline Total & 3 & 5.7 & 16 & 30.2 & 34 & 64.1 & 53 & 100 & \\
\hline
\end{tabular}

Sumber : Data Primer, 2020

Berdasarkan Tabel 3 menunjukkan frekuensi tertinggi adalah yang mempunyai aktivitas fisik cukup yaitu $34(79,1 \%)$ tidak mengalami demensia dan frekuensi terendah adalah yang aktivitas fisiknya kurang, yaitu 3 (30\%) yang tergolong demensia berat.

Hasil uji korelasi spearman rank diperoleh angka signifikan atau p-value (0.000) jauh lebih rendah standar sifnifikan dari 0.05 atau $(\mathrm{p}<\alpha)$ dapat disimpulkan bahwa $\mathrm{H}_{0}$ ditolak dan $\mathrm{H}_{1}$ diterima sehingga kesimpulannya; ada hubungan antara aktivitas fisik dengan demensia pada lanjut usia. 


\section{PEMBAHASAN}

\section{Hubungan antara Kebiasaan Membaca Al-Qur'an dengan Demensia}

Kebiasaan mengaji atau membaca Al-Qur'an dengan intensitas selalu/sering serta durasi waktu membaca minimal 15 menit dapat mempertahankan fungsi kognitif pada manusia terlebih pada lanjut usia yang sangat rentan terhadap penyakit penurunan fungsi kognitif seperti demensia dan depresi(11). Dari hasil uji statistik diperoleh nilai $p$-value $=0.000$ atau $\mathrm{p}<\alpha$ dapat disimpulkan bahwa terdapat hubungan antara kebiasaan membaca Al-Qur'an dengan demensia pada lanjut usia/ lansia.

Dalam proses penuaan, keadaan menua merupakan keadaan yang tidak bisa kita hindari dan akan dialami oleh seluruh manusia yang hidup di muka bumi. Seiring bertambahnya umur seseorang, maka akan terjadi juga yang namanya penurunan fungsi kognitif seperti berkurangnya kemampuan dalam berfikir, kurang konsentrasi, berkurangnya daya ingat, hal ini disebabkan karena menuanya sel-sel pada otak. Kemampuan kognitif lansia dapat diperlambat dengan melakukan aktivitas kognitif seperti aktivitas membaca (11).

Dari hasil penelitian didapatkan ada 93,9\% lanjut usia yang kebiasaan membaca AlQur'annya cukup, mereka tidak menderita demensia. Menurut peneliti, orang yang berada pada usia lanjut cenderung berusaha mempersiapkan diri dan meningkatkan iman dan takwa sebagai persiapan menghadapi ajalnya. Hal ini juga terlihat pada lansia yang ada di desa Baringeng, meskipun umur mereka sudah tua kebanyakan lansia masih tampak aktif dalam kegiatan pengajian, bahkan sebagian ada yang mengisi aktivitas hariannya dengan mengajarkan anak-anak mengaji/ membaca Al-Qur'an.

Dari beberapa responden yang diberikan pertanyaan tentang kebiasaan membaca AlQur'an, sebagian besar responden menjawab bahwa mereka membaca Al-Qur'an hampir setiap harinya setiap selesai melaksanakan shalat. Mereka mengaji dalam keadaan mempunyai wudhu dan dengan durasi membaca Al-Qur'an rata-rata 15 menit. Hasil ini sejalan dengan penelitian oleh Rahmawati (2020) di Puskesmas Jumpandang Baru Makassar yang mana didapatkan hasil bahwa terdapat hubungan frekuensi membaca Al-Qur'an dan berdzikir dengan kejadian demensia dengan nilai $\mathrm{p}=0,000$ (13). Hal ini artinya kejadian demensia dapat dikurangi/diminimalisir dengan cara selalu mengaji atau baca qur'an.

Jika dilihat dari pendidikan responden, pendidikan seseorang juga dapat mempengaruhi risiko demensia, yang mana pendidikan dapat mempengaruhi berat otak seseorang, dapat mengkompensasi semua jenis neurodegenerative, termasuk juga gangguan vaskular (13). Dalam penelitian ini kebanyakan responden tidak menamatkan pendidikan sekolah dasar, namun hasil yang didapatkan justru banyak dari mereka yang tidak mengalami demensia. Peneliti berasumsi bahwa meskipun tingkat pendidikan responden rendah, namun dengan adanya kebiasaan-kebiasaan positif yang rutin dilakukan oleh lanjut usia seperti kebiasaan membaca Al-Qur'an dan berbagai aktivitas fisik, maka kejadian demensia dapat diperlambat. Hasil ini tidak sejalan dengan penelitian deskriptif oleh Insani (2019) yang menemukan 65\% responden yang memiliki gangguan kognitif lebih banyak terjadi pada tingkat pendidikan tidak tamat SD. Rendahnya tingkat pendidikan membuat kebanyakan responden merasa malas untuk melakukan aktivitas mental, seperti membaca dan menulis karena membutuhkan waktu yang cukup banyak dan pemikiran yang berat.(14). Sementara jika dilihat dari data jenis kelamin, 73,6\% lansia dalam penelitian ini adalah perempuan, namun tidak ada perbedaan kebiasaan membaca Alqur'an antara laki-laki dan perempuan, sedangkan untuk kejadian demensia itu sendiri baik perempuan maupun laki-laki yang memiliki kebiasaan membaca AlQur'an cukup, tidak mengalami demensia.

Menurut Haeroni membaca Al-Qur'an mampu menghantarkan getaran-getaran suara yang diterima oleh telinga yang kemudian mengalir masuk ke dalam sel otak, setelah masuk ke dalam sel otak tersebut kemudian memberikan efek pada medan elektronik yang 
sebelumnya telah berada dalam sel dan akhirnya sel-sel pun memberikan respon terhadap medan-medan tersebut dan mengimbangi getaran yang diberikan. Perubahan getaran tersebut hanya akan ditemukan apabila dilakukan secara panjang dan terus-menerus (11). Pada hasil penelitian Irawati (2019) mengemukakan bahwa kebiasaan membaca Al-Qur'an dengan durasi tertentu dan dikerjakan pada waktu-waktu terbaik dapat mempertahankan kemampuan kognitif lansia dan mencerminkan sikap positif lansia. Hasil test bivariat menunjukkan adanya hubungan antara lamanya durasi membaca Al- Qur`an dengan turunnya fungsi kognitif pada lansia, p- value $=0.001$ (11)

Pada sebuah eksperimen yang mengukur kemampuan daya ingat, dimana didapatkan perbedaan yang signifikan pada kemampuan daya ingat yang didapatkan dari free recall test di kelompok eksperiman sebelum dan sesudah diberikan intervensi membaca Al-Qur'an selama 15 menit, berbeda dengan kelompok kontrol yang diberikan placebo berupa membaca cerita tentang dunia hewan tidak ada perbedaan sebelum dan sesudahnya (11). Penelitian tersebut semakin memperkuat hasil bahwa terdapat hubungan antara kebiasaan seseorang membaca Al-Qur'an dengan kemampuan kognitifnya.

Dalam ajaran islam, setiap orang diperintahkan oleh Allah dan Rasul-Nya untuk membaca Al-Qur'an dan juga diperintahkan untuk menghayati isi bacaan lalu kemudian mengamalkannya. Membaca Al-Qur'an akan memberdayakan lisan, penglihatan, pendengaran begitupun dengan akal dan hati untuk merasakan keheningan bacaan dan sentuhan makna dari setiap ayat yang dibacanya, sehingga memunculkan rasa ketenangan (15)

Al-Qur'an memang memiliki banyak keutamaan, merupakan obat yang dapat menyembuhkan, orang yang selalu membiasakan diri membaca ayat-ayat Al-Qur'an hatinya akan selalu tenang sehingga jauh dari penyakit depresi ataupun pikun, selain itu akan mendapat kesempurnaan pahala. Allah Subhanahu wa ta'ala berfirman dalam QS Fatir/35: 2930 yang terjemahannya; "Sesungguhnya orang-orang yang selalu membaca kitab Allah dan mendirikan salat dan menafkahkan sebagian dari rezeki yang Kami anugerahkan kepada mereka dengan diam-diam dan terang-terangan, mereka itu mengharapkan perniagaan yang tidak akan merugi, agar Allah menyempurnakan kepada mereka pahala mereka dan menambah kepada mereka dari karunia-Nya. Sesungguhnya Allah Maha Pengampun lagi Maha Mensyukuri.’(QS. Fatir : 29-30) (16).

\section{Hubungan antara Aktivitas Fisik dengan Demensia}

Berdasarkan uji korelasi spearman rank didapat $p$-value $=0.000$ atau $\mathrm{p}<\alpha$ sehingga disimpulkan bahwa aktivitas fisik memiliki hubungan signifikan dengan kejadian demensia pada lansia. Sebagaimana dalam proses penuaan, bertambahnya umur seseorang juga akan berpengaruh pada kemampuan fisik dan fungsi kognitifnya, namun ini adalah hal yang alami bagi setiap lansia dan keadaan ini dapat diperlambat dengan cara rutin melakukan aktivitas fisik.(17). Hal ini dapat terlihat dari lansia yang ada di desa Baringeng yang menurut pengamatan peneliti meskipun umur mereka sudah tua namun rata-rata lanjut usia yang ditemui dirumahnya saat penelitian berlangsung, mereka masih sangat aktif bergerak dan melakukan aktivitas fisik seperti menyapu halaman, mencabut rumput, berkebun di belakang rumah dsb. Selain itu, sebagian besar lanjut usia masih mengingat nama hari, tanggal, bulan maupun tahun saat diberi pertanyaan/ kuesioner tanpa terlalu lama berfikir panjang, dan begitupun dengan pertanyaan yang lain, mampu dijawab dengan baik, mayoritas lanjut usia tidak mengalami demensia. Hasil yang didapatkan ini sejalan dengan penelitian yang dilakukan oleh Nety Mawarda (2019) pada lansia di Mananggal Surabaya yang mendapatkan hasil bahwa terdapat pengaruh terapi gerakan senam dan latihan puzzle pada penyakit demensia dengan nilai $\mathrm{p}=0,015$ (9). 
Menurut jenis kelamin, sebagian besar lansia yaitu 73,6\% adalah perempuan, ini disebabkan karena perempuan memiliki usia harapan hidup yang lebih panjang dibanding laki-laki, namun pada umumnya perempuan dianggap mahluk yang lemah dalam melakukan aktivitas fisik yang membutuhkan kekuatan otot, hal ini ternyata tidak berlaku di desa Baringeng. Menurut pengamatan peneliti, lansia perempuan ataupun laki-laki yang ada di desa Baringeng rata-rata masih aktif dalam beraktivitas seperti berkebun dan mengerjakan sawahnya. Sementara dari segi pendidikan, kebanyakan lansia di desa Baringeng tidak tamat sekolah dasar, hal ini tentu mempengaruhi jenis aktivitas kesehariannya dalam pemenuhan kebutuhan hidupnya. Disebabkan oleh rendahnya tingkat pendidikan lansia di desa ini, sehingga dari dulu mereka hanya bisa berkebun dan mengerjakan sawah. Jenis aktivitas ini tentunya banyak membutuhkan tenaga ataupun kekuatan otot, sehingga bisa dibilang lansia di desa Baringeng sudah terbiasa dalam melakukan aktivitas fisik sejak mereka masih muda. Dari hasil yang diperoleh ada sekitar 79,1\% lansia di desa Baringeng yang memiliki aktivitas fisik cukup, tidak menderita demensia.

Beberapa penelitian sebelumnya juga memperkuat hasil penelitian ini, salah satunya adalah penelitian Adreany (2017), yang mana dalam penelitiannya ia memberi perlakuan berupa latihan fisik pada lansia. Latihan fisik yang diberikan terdiri dari senam irama, latihan kekuatan dan kelenturan, setelah dilakukan intervensi latihan/gerak fisik, maka ada peningkatan sebesar 2,10 poin dari nilai Mini Mental State Examination (MMSE) sebelum diberikan perlakuan.(8). Ada juga penelitian yang dilakukan oleh Budiriyanto (2016) yang mana hasil penelitiannya menunjukkan bahwa mereka yang tidak pernah jalan kaki 1,46 kali lebih berisiko mengalami penurunan pada fungsi kognitif, dibandingkan dengan orang yang rutin jalan kaki lebih dari 1 x seminggu.(18). Sementara hasil penelitian deskriptif yang dilakukan oleh Asep Mulyadi (2017) menunjukkan bahwa dari 46 responden ada sekitar $52,2 \%$ yang mengalami demensia dikarenakan aktivitas fisik yang kurang. Dari semua hasil peneltian yang disebutkan diatas dapat menjadi bukti bahwa aktivitas fisik memang sangat berpengaruh dengan kejadian demensia (19).

Gomez-Pinilla dalam Wahyuni (2016) menyatakan bahwa sesudah melakukan aktivitas fisik, denyut jantung seseorang akan meningkat dan juga akan terjadi vasodilatasi pembuluh darah, hal ini membuat sirkulasi darah dapat menjangkau otak dan seluruh tubuh. Dengan meningkatnya sirkulasi darah, maka menyebabkan suplay oksigen dan nutrisi juga menjadi lancar, ini membuat fungsi otak menjadi optimal dan tentunya meningkatkan daya ingat. Jadi, dapat dikatakan bahwa gerak fisik sangat penting dalam menjaga daya ingat/memori seseorang (20).

Fisik yang sehat adalah anugerah terbesar dari Sang Khalik sehingga sebagai bentuk syukur kita pada-Nya, maka wajib bagi setiap manusia untuk menjaga kesehatan tubuhnya. Salah satu kegiatan yang dapat dilakukan adalah dengan rutin melakukan latihan atau Aktivitas fisik agar aliran darah lancar dan metabolisme tubuh menjadi seimbang, sebagaimana hadis nabi: Dari Abu Hurairah Radiyallahu Anhu ia berkata: Rasulullah Sallallahu Alaihi Wasallam bersabda: "Orang mukmin yang kuat itu lebih baik dan lebih dicintai oleh Allah daripada orang mukmin yang lemah, namun pada masing-masing (dari keduanya) ada kebaikan. Bersemangatlah terhadap hal-hal yang berguna bagimu, mohonlah pertolongan kepada Allah, dan jangan menjadi lemah. Jika kamu ditimpa sesuatu, jangan berkata seandainya aku berbuat begini, maka akan begini dan begitu, tetapi katakanlah Allah telah menakdirkan, dan kehendak oleh Allah pasti dilakukan, sebab kata 'seandainya' itu dapat membuka perbuatan setan”(HR. Muslim no.2664) (21). 


\section{SIMPULAN}

Kebiasaan membaca ayat al-Qur'an dan aktivitas fisik berhubungan signifikan dengan penyakit demensia pada lanjut usia/lansia

\section{SARAN}

Bagi peneliti selanjutnya diharapkan akan ada yang mengembangkan topik ini dengan mengambil komponen/variabel yang berbeda dan tidak hanya fokus pada aktivitas fisik dan kebiasaan membaca Al-Qur'an saja, sebab peneliti merasa masih banyak faktor lain yang bisa mempengaruhi penyakit demensia, diharapkan peneliti berikut dapat mengambil variabel yang ada kaitannya dengan kebiasaan-kebiasaan yang dicontohkan oleh Baginda Rasulullah Shallallahu 'alaihi wa sallam untuk dihubungkan dengan kejadian demensia, seperti kebiasaan sholat tahajud, kebiasaan berpuasa senin kamis, kebiasaan melakukan silaturahmi, kebiasaan menjaga pola makan dll, sehingga diharapkan dapat menambah khasanah ilmu kita tentang demensia.

\section{UCAPAN TERIMA KASIH}

Peneliti menyampaikan rasa terimakasih pada pihak pemerintah Kabupaten Soppeng dalam hal ini Dinas Kesehatan Kabupaten Soppeng dan segenap pihak Puskesmas Baringeng yang telah memberikan kesempatan pada peneliti untuk meneliti di tempat tersebut, dan khusus pada kader Posyandu Lansia yang senantiasa ikhlas mendampingi dan membantu peneliti saat pengumpulan data di lapangan.

\section{DAFTAR PUSTAKA}

1. Kemenkes RI. Menkes: lansia yang sehat, lansia yang jauh dari demensia. Kementeri Kesehat RI [Internet]. 2017;(021):1. Tersedia pada: http://www.depkes.go.id/article/view/17070700004/program-indonesia-sehat-denganpendekatan-keluarga.html

2. Alzheimer Association. Kasus Demensia [Internet]. 2019. Tersedia pada: https://alzi.or.id/statistik-tentang-demensia/

3. Kementerian Kesehatan RI Badan Penelitian dan Pengembangan. Hasil Utama Riskesdasr. Kementrian Kesehat Republik Indones [Internet]. 2018;1-100. Tersedia pada: http://www.depkes.go.id/resources/download/info-terkini/hasil-riskesdas-2018.pdf

4. Statistik BP. Statistik Penduduk Lanjut Usia. Sulawesi Selatan; 2018.

5. Badan Pusat Statistik. Statistik Penduduk Kabupaten Soppeng. Kabupaten Soppeng SulSel; 2019.

6. Facts A statistic K. Dementia Australia. Australia; 2020. Tersedia pada: https://www.dementia.org.au/statistics

7. Kuswati Ani, Sumedi Taat W. Elderly Empowerment Through The Activities Of Brain Function Cognitive Stimulation Elderly In Mersi Village District Banyumas. J Bionusing [Internet]. 2019;1 Nomor 2:122-32. Tersedia pada: http://bionursing.fikes.unsoed.ac.id/bion/index.php/bionursing/article/view/19

8. Kusumowardani A, Wahyuni ES. Pengaruh Latihan Fisik Terhadap Kemampuan Kognitif Lansia Di Desa Ngesrep Kecamatan Ngemplak Kabupaten BoyolaliALI. Jurnal Ilmu Kesehatan. 2017;6(2):168-78.

9. Hatmanti NM, Yunita A. Senam Lansia dan Terapi Puzzle terhadap Demensia pada Lansia. J Keperawatan Muhammadiyah. 2019;4(1):104-7.

10. Al-Finatunni'mah A, Nurhidayati T. Pelaksanaan Senam Otak untuk Peningkatan Fungsi Kognitif pada Lansia dengan Demensia. Ners Muda. 2020;1(2):139.

11. Irawati K, Madani F. Durasi Membaca Al-Qur'an dengan Fungsi Kognitif pada Lansia. 
Mutiara Med J Kedokt dan Kesehat. 2019;19(1):17-22.

12. Linda Rosdiana N. Hubungan Kebiasaan Membaca Al-Qur'an Dengan Fungsi Kognitif Pada Lansia Di Panti Sosial Tresna Werdha Budi Mulia 02 Cengkareng Jakarta barat Tahun 2017. Jakarta Barat; 2017.

13. Ramli R, wulandari ladewan. Faktor Yang Berhubungan Dengan Kejadian Demensia Di Puskesmas Jumpandang Baru Kecamatan Tallo Kota Makassar. J Med Hutama [Internet]. 2020;01(02):78-85. Tersedia pada: http://jurnalmedikahutama.com

14. Insani Kamila Tanjung, Ari Udiyono NK. Gambaran Gangguan Kognitif Dan Fungsional (Iadl)Padalansia Di Kelurahan Kramas, Kecamatan Tembalang, Kota Semarang. J Kesehat Masy. 2019;7(1):168-75.

15. Musthofa. Adab Membaca Al-Qur'an. Jurnl An-Nuha. 2017;4(1).

16. RI DA. Al-Qu'an Terjemahan. Bandung: CV. Darus Sunnah; 2015.

17. Craft S, Cholerton B, Reger M. Cognitive Changes Associated with Normal and Pathological Aging. Hazzard's Geriatr Med Georontology. 2016;751-3; 46; 781; 757.

18. Wreksoatmodjo BR. Pengaruh Aktivitas Fisik terhadap Fungsi Kognitif Lanjut Usia di Jakarta. Cdfk. 2016;43(1):7-12.

19. Mulyadi A, Anisa Fitriana L, Rohaedi S. Gambaran aktivitas fisik pada lansia demensia di balai perlindungan sosial tresna wreda ciparay bandung. J Keperawatan Olahraga. 2020;9(1):1-11.

20. Wahyuni A, Nisa K. Pengaruh Latihan Fisik terhadap Fungsi Kognitif pada Penderita Demensia. Majority. 2016;5(4):12-6.

21. Al-Bukhari, Abu Abdullah Muhammad bin Ismail Abdul Rasyid, Masyhar MA, Muhammad Suhadi, Nanang Ni' amurrahman S. Ensiklopedia Hadis. In: hadis [Internet].2011.Tersediapada:https://opac.perpusnas.go.id/ResultListOpac.aspx?pDataIte $\mathrm{m}=\mathrm{Al}$-Bukhari, Abu Abdullah Muhammad bin Ismail\&pType=Author\&pLembarkerja=$1 \& p P i l i h a n=$ Author 